\section{Microbiological Seal of Two Types of Tapered Implant Connections}

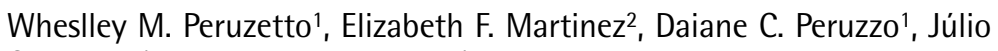
Cesar Joly ${ }^{1}$, Marcelo H. Napimoga ${ }^{1}$
'Laboratory of Immunology and Molecular Biology, SLMANDIC - São Leopoldo Mandic Institute and Research Center, Campinas, SP, Brazil ${ }^{2}$ Laboratory of Oral Pathology, SLMANDIC - São Leopoldo Mandic Institute and Research Center, Campinas, SP, Brazil

Correspondence: Dr. Marcelo $\mathrm{H}$. Napimoga, Rua José Rocha Junqueira, 13, 13045-755, Campinas, SP, Brasil. Tel: +55-19-3211-3627/36. e-mail: marcelo.napimoga@gmail. com ornapimogamh@yahoo.com

\begin{abstract}
Tapered implant connections have gained wide popularity for being more resistant to fatigue and for promoting a better seal against bacterial infiltration than conventional connections. The aim of this study was to evaluate the bacterial seal at the implantabutment interface using two Morse taper implant models, by in vitro microbiological analysis. Eleven non-indexed and 11 indexed abutments were selected and connected to their respective implants with a $20 \mathrm{~N}$ torque, according to manufacturer's recommendation. Microbiological analysis was carried out using colonies of Escherichia coli transported directly from a culture dish to the prosthetic component. For control, one non-contaminated abutment-implant set from each group (negative control) and one contaminated implant with no abutment (positive control) were used. The specimens were immersed in BHI broth and maintained in an incubator at $37^{\circ} \mathrm{C}$ for 14 days to assess the development of bacterial contamination. The results revealed that $36.4 \%(n=4)$ of the indexed components and $90.9 \%(n=10)$ of the non-indexed components allowed bacterial leakage, with significant difference between groups ( $p=0.0237)$. In conclusion, both tapered components failed to provide adequate sealing to bacterial leakage, although the indexed type components showed a superior seal compared with non-indexed components.
\end{abstract}

\section{Introduction}

Implant systems differ in shape at the abutment/ implant interface, especially between tapered and nontapered connections (internal and external hexagons). Such interface is the weakest link in implant-supported prostheses, since it is associated with the incidence of masticatory loads that may reduce abutment stability (1). The interface is located at the level of the alveolar crest, so it is subject to possible microbial colonization (2). Therefore, the presence of a gap between the abutment and the implant is one of the main factors contributing to periimplantitis (3) leading to marginal bone loss (4). It is generally accepted that all implant systems with two components leave a microscopic space at the interface between the implant and the prosthetic abutment. This space may facilitate penetration of fluid and macromolecules derived from the crevicular fluid and saliva (5). Design differences at the implant-abutment connections may influence the risk of bacterial colonization (6).

Some connections may promote greater resistance to displacement by axial and lateral forces (7). Tapered connection systems are believed to solve this problem, since this gap should be much narrower, delaying and even preventing a possible bacterial colonization $(6,8)$. This hypothesis is derived from the principle that the Morse taper is a fitting design in which a cone with an angulation between 2 and 4 degrees is embedded in another cone by friction, without the need for screws, creating a cold weld between the parts (9).
In this context, it is essential that the seal between the abutment and the implant is effective in order to prevent or decrease the risk of bacterial colonization, since the higher the proximity of the micro-gap location to the alveolar bone the greater the expected bone loss (10). Despite the implant/abutment interface not following exactly the configurations and angles of the Morse taper mechanisms, they have been shown to be stable, strong, predictable and appropriate for load bearing (11) without loosening the abutment screws (9).

The use of Morse taper connection implants is becoming more widespread in single-tooth, partial or full mouth rehabilitations with undeniable benefits and clinical longevity. There are several brands and implant models with this type of connection currently available for the clinician. In this study, were evaluated two different types of abutments with Morse taper connections for the same implant model: an indexed tapered connection with a through screw and a solid non-indexed tapered connection. Therefore, the aim of this study was to evaluate the bacterial seal at the implant-abutment interface using two Morse taper implant models, by in vitro microbiological analysis.

\section{Material and Methods}

Two types of tapered implant abutment connections (3.8 $\times 10 \mathrm{~mm}$ with a 16-degree tapered platform; Sistema de Implantes-SIN, São Paulo, SP, Brazil) were evaluated. The materials used in the study (implants, prosthetic components and torque wrench) were provided by the 
manufacturer with no conflict of interests.

Eleven sets of indexed tapered connection components and eleven sets of non-indexed tapered connection components were used (Fig. 1) for the microbiological analysis. The implants were strong SW Morse SWCM3810 (SIN) and the abutments were cemented indexed component AIMP4001C-H and Universal Abutment AIM42401C. In addition, for each model, an implant with its respective prosthetic abutment was used as a negative control and a set without the abutment as a positive control of microbial contamination. A single trained and calibrated operator in a laminar flow hood previously sanitized and lined with a sterile sheet performed the procedures.

The most apical portion of each abutment retaining screw was contaminated with strains of Escherichia coli obtained from ATCC 25922 (American Type Culture Collection, USA). For this purpose, colonies grown on BHI agar (Brain Heart Infusion, Himedia, Mumbai, India) for 24 $\mathrm{h}$ in a bacteriological incubator at $37^{\circ} \mathrm{C}$ were transferred using rods made from sterilized orthodontic wire, avoiding contamination of the external surfaces.

The abutment was immediately adapted to the corresponding implant using a manual torque wrench (SIN,

São Paulo, SP, Brazil) at $20 \mathrm{~N}$ following the manufacturer's

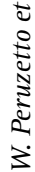

specifications. The implants were fixed and stabilized with a sterile bench vise. Each implant-abutment set was immersed in a test tube containing $1 \mathrm{~mL}$ of BHI broth.

In order to ensure a contamination-free outer surface, each specimen was swabbed around the abutment/implant interface using a microbrush dipped in $0.9 \%$ saline prior to immersion of the implants in the BHI broth (12). Each microbrush was also immersed into culture medium as control for external contamination. As positive control, one implant from each group was inoculated with $E$. coli strains, under the same conditions as described above and immersed in $\mathrm{BHI}$ broth without abutment, following the same culture conditions. As negative control, one implant from each group was incubated sterile with the connecting prosthetic abutment.

All tubes were identified and kept upright in a bacteriological incubator for 14 days at $37{ }^{\circ} \mathrm{C}$ under aerobic conditions. The specimens were checked every 24 h. Turbidity of the culture broth or deposits at the bottom of the tubes indicated macroscopically the failure of abutment/implant seal against bacterial leakage. Aliquots were collected from the culture medium of the test tubes $(10 \mu \mathrm{L})$ from each sample suspected of contamination and seeded on $\mathrm{BHI}$ and incubated in agar at $37{ }^{\circ} \mathrm{C}$ for 24 $h$. This step was to confirm the findings from the visual macroscopic examination of $E$. coli growth by Gram staining.

After 14 days, the implants were

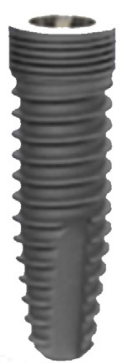

A

B

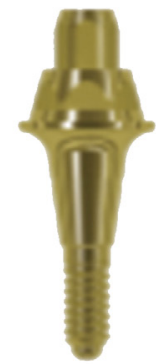

$\mathbf{C}$

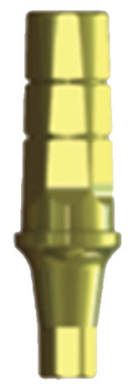

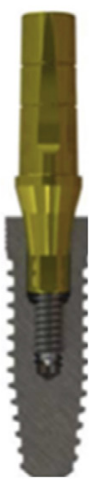

Figure 1. Morse taper implants and abutments. A: Strong SW Morse implant model by SIN; B: Universal non-indexed Morse taper abutment; C: Cemented indexed Morse taper abutment; D: Sagittal section of an implant with an indexed abutment. removed from the culture medium and their components disconnected via counter-torque using forceps and the same wrench used for fastening. Failure of the abutment/ implant interface seal was observed via turbidity or presence of deposits in the culture. Figure 2 synthesizes the used microbiological protocol.

Descriptive analysis of the data was performed in terms of absolute frequency and relative frequency (percentage). Fisher's exact test was used at a significance level of $5 \%$ (Table 1).

\section{Results}

Table 1. Absolute and relative frequency (percentage) of the presence and absence of broth turbidity, according to the type of shoulder (indexed and non-indexed). Fisher's exact test $(p<0.05)$

\begin{tabular}{lccc}
\hline \multirow{2}{*}{ Implants } & \multicolumn{2}{c}{ Bacterial contamination } & \\
\cline { 2 - 3 } & Present & Absent & \\
\hline Indexed shoulder & $04(36.3 \%)$ & $07(63.7 \%)$ & \\
Non-indexed shoulder & $10(90.9 \%)$ & $01(9.1 \%)$ & $\mathrm{p}=0.0237$ \\
\hline
\end{tabular}

Failure of the abutment/implant interface seal was observed via turbidity or presence of deposits in the culture broth in $4 / 11$ (36.4\%) of the indexed components, whereas 10/11 (90.9\%) of the non-indexed components were contaminated, revealing a significant difference between the groups ( $p=0.0237$, Fisher's exact test). No turbidity was observed either in the tubes containing 
the microbrushes used as control for abutment/implant interface contamination or in the negative controls.

Figure 3 illustrates the follow-up of specimens for 14 days, where the group containing the indexed components showed contamination of the first culture medium on the eighth day. In the group of non-indexed components, 6 samples were contaminated in the first day.

\section{Discussion}

Although a large number of studies report favorable survival rates with the use of dental implants in various situations, complications of organic and prosthetic nature could affect implant-supported restorations, especially in the long term (13).

Two-piece implant designs are not devoid of gaps between the implant and the abutment, which favors infiltration of bacteria and induces inflammatory reactions in the periimplant tissues. The results of this study demonstrated that implants with indexed tapered components showed a superior seal (preventing bacterial leakage) to implants with non-indexed tapered components, and a statistically significant difference between the groups. In the group of non-indexed components, 6 samples showed bacterial leakage from day 1 , whereas in the indexed group, contamination of the first sample medium occurred only on the 8th day. The presence of the index may have been the determining factor behind the difference in sealing capacity between the groups. The superior seal observed in that group may be explained by a more accurate adaptation than the one encountered in strictly tapered components.
This would also explain the increased difficulty to remove the indexed component from the implant by countertorqueing. Supporting the present results, Schmitt et al. (14) suggested that no cold welding may be obtained in nontapered systems and the tapered interface provides a more precise fit. However, Jansen et al. (2) found no difference between 13 combinations of implant/abutment systems, including tapered, non-tapered and tapered indexed, where all combinations showed bacterial leakage in vitro and most samples showed contamination on the first day. Scanning electron microscopy analysis showed mismatches smaller

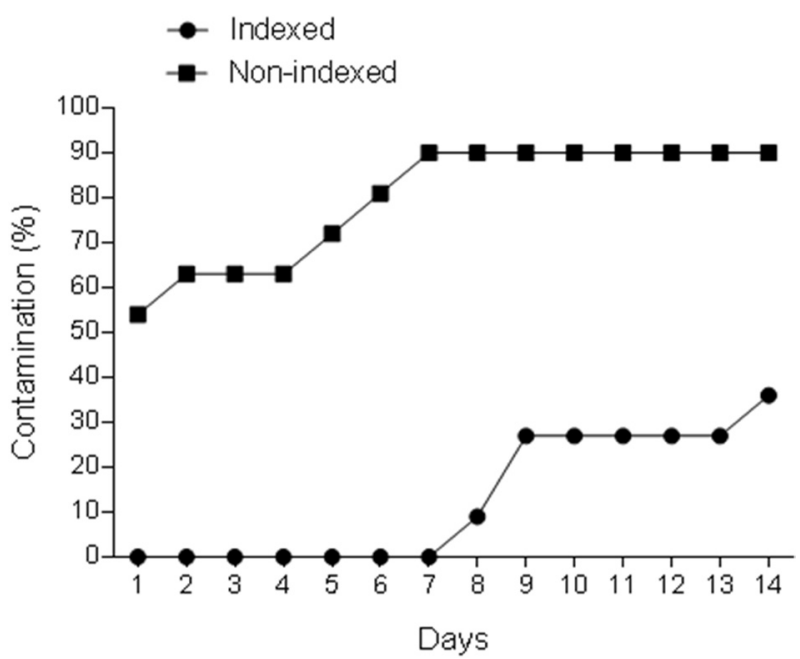

Figure 3. Abutment/implant contamination follow-up expressed as percentage over 14 days.

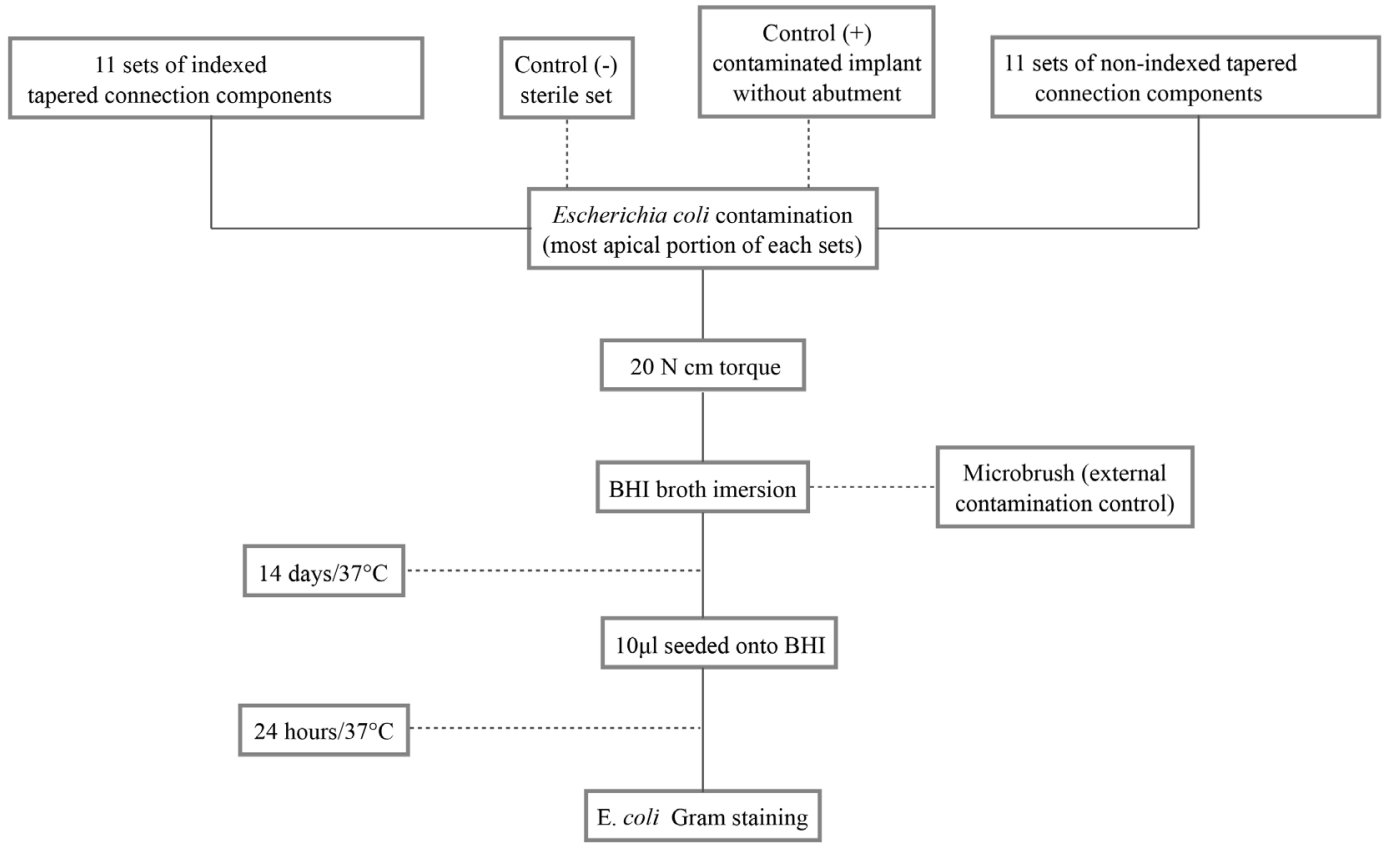

Figure 2. Flow chart summarizing the microbiological protocol. 
than $10 \mu \mathrm{m}$ for all samples.

Although screwed tapered abutments are regarded as Morse taper, their connection resembles the external hexagon, since the abutment is only supported by the screw that passes the abutment and connects it to the implant, causing only a mild friction between surfaces (15). However, in this study the indexed prosthetic component showed great resistance to implant disconnection even after screw removal, suggesting a greater degree of imbrication between the surfaces than the strictly conical components (non-indexed), which may explain the better seal in the former group.

The screwing torque used was $20 \mathrm{~N}$, as recommended by the manufacturer for both types of abutments. Increasing the torque beyond $30 \mathrm{~N}$ may be beneficial for the stability of the implant-abutment and reduce the risk of loose screws $(16,17)$. Furthermore, increased screwing torque in Morse taper connections improves their sealing capacity, since no contamination was observed for abutments tightened with a $40 \mathrm{~N}$ torque (18). Alves et al. (12) also concluded that the difference in tightening torque changed the sealing ability of the abutment/implant sets, and the group of 20 $\mathrm{N}$ torque showed more contamination than the group that was tightened with a $30 \mathrm{~N}$ torque and this difference was statistically significant. Increasing the torque could improve the seal of the evaluated implants, however this would be against the manufacturer's recommendations. Furthermore, if the screws are not designed for torques above $20 \mathrm{~N}$, they could be weakened and fracture, which could jeopardize the entire set by the ambition of ameliorating the seal.

A mechanical torque wrench was used for tightening the screws as well as for removing them, making it impossible to accurately measure the removal torque values. However, it was evident that the removal torque for both groups was lower than $20 \mathrm{~N}$. This reduced torque can be justified by the wide angle of $16^{\circ}$ of this type of implant, which is well above the $8^{\circ}$ angle of the implant evaluated by Sutter et al. (9). The authors observed that removal torque values were up to $15 \%$ higher than the tightening torque, and far from the $3.014^{\circ}$ of the true Morse-taper design recommended by the Brazilian Association of Technical Standards (ABNT).

When not subjected to load, the degree of bacterial contamination inside the abutment/implant set was influenced mainly by the precision of the fit between the components and the screw torque (5). Schmitt and colleagues (14) demonstrated that the tapered connections were superior regarding their sealing capacity in vitro, more resistant to abutment movement as well as to widening of the abutment/implant interface under load. They also presented greater resistance to fatigue. Moreover, this system causes less stress on the screw than the external hexagon and may be compared with the internal hexagon system. These two systems are inferior regarding abutment movement and microgap formation in the abutment/ implant interface. In the present study, none of the evaluated components was able to prevent bacterial leakage in vitro, even so, indexed tapered abutments showed superior results than non-tapered abutments. More studies are required to assess the accuracy of the fit between the two components and the implant, in addition to the seal obtained by the load application.

\section{Resumo}

Conexões de implantes cônicos cresceram em popularidade por serem mais resistentes à fadiga e por promover uma melhor vedação contra infiltração bacteriana do que as conexões convencionais. 0 objetivo deste estudo foi avaliar o selamento bacteriano na interface implante-pilar utilizando dois modelos de implantes cone Morse, por meio de análise microbiológica in vitro. Onze pilares não indexados e 11 pilares indexados foram selecionados e conectados aos seus respectivos implantes com um torque de $20 \mathrm{~N}$, de acordo com a recomendação do fabricante. A análise microbiológica foi realizada utilizando colônias de Escherichia coli retirados diretamente a partir de uma placa de cultura para o componente protético. Para os grupos de controle, foi utilizado um pilar-implante não contaminado de cada grupo (controle negativo) e um implante contaminado sem pilar (controle positivo). Os espécimes foram imersos em caldo $\mathrm{BHI}$ e mantidos numa incubadora a $37^{\circ} \mathrm{C}$ durante 14 dias, para monitorar o desenvolvimento de contaminação bacteriana. Os resultados revelaram que $36,4 \%(n=4)$ dos componentes indexados e $90,9 \%(n=10)$ dos componentes não indexados obtiveram infiltração bacteriana, com diferença significativa entre os grupos $(p=0,0237)$. Como conclusão, os dois componentes cônicos não conseguiram proporcionar uma vedação adequada contra infiltração bacteriana, embora os componentes do tipo indexados mostrassem uma vedação superior, quando comparados com componentes não indexados.

\section{Acknowledgements}

The authors gratefully acknowledge financial support from the Brazilian funding agency National Council for Scientific and Technological Development (CNPq). MHN was supported by a research fellowship grant \#303555/2013-0 (CNPq).

\section{References}

1. Koutouzis $T$, Wallet $S$, Calderon $N$, Lundgren $T$. Bacterial colonization of the implant-abutment interface using an in vitro dynamic loading model. J Periodontol 2011;82:613-618.

2. Jansen VK, Conrads G, Richter EJ. Microbial leakage and marginal fit of the implant-abutment interface. Int J Oral Maxillofac Implants. 1997;12:527-540.

3. Goiato MC, Pellizzer EP, Silva EV, Bonatto LR, Dos Santos DM. Is the internal connection more efficient than external connection in mechanical, biological, and esthetical point of views? A systematic review. Oral Maxillofac Surg 2015;19:229-242.

4. Koutouzis T, Gadalla H, Kettler Z, Elbarasi A, Nonhoff J. The role of chlorhexidine on endotoxin penetration to the implant-abutment interface (IAI). Clin Implant Dent Relat Res 2015;17:476-482.

5. Gross M, Abramovich I, Weiss EL. Microleakage at the abutmentimplant interface of osseointegrated implants: a comparative study. Int J Oral Maxillofac Implants 1999;14:94-100.

6. Tesmer M, Wallet $\mathrm{S}$, Koutouzis $\mathrm{T}$, Lundgren T. Bacterial colonization of the dental implant fixture-abutment interface: an in vitro study. J Periodontol 2009;80:1991-1997.

7. Maeda Y, Satoh T, Sogo M. In vitro differences of stress concentrations for internal and external hex implant-abutment connections: a short 
communication. J Oral Rehabil 2006:33:75-78.

8. Merz BR, Hunenbart $S$, Belser UC. Mechanics of the implant-abutment connection: an 8-degree taper compared to a butt joint connection. Int J Oral Maxillofac Implants 2000;15:519-526.

9. Sutter F, Weber HP, Sorensen J, Belser U. The new restorative concept of the ITI dental implant system: design and engineering. Int J Periodontics Restorative Dent 1993;13:409-431.

10. Dhir S. The peri-implant esthetics: An unforgettable entity. J Indian Soc Periodontol 2011;15:98-103.

11. Norton MR. The Astra Tech single-tooth implant system: a report on 27 consecutively placed and restored implants. Int J Periodontics Restorative Dent 1997;17:574-583.

12. Alves DC, Carvalho PP, Martinez EF. In vitro microbiological analysis of bacterial seal at the implant-abutment interface using two Morse taper implant models. Braz Dent J 2014;25:48-53.

13. Mangano C, laculli F, Piattelli A, Mangano F. Fixed restorations supported by Morse-taper connection implants: a retrospective clinical study with 10-20 years of follow-up. Clin Oral Implants Res. 2015;26:1229-1236.

14. Schmitt CM, Nogueira-Filho G, Tenenbaum HC, Lai JY, Brito C, Döring
$\mathrm{H}$, et al.. Performance of conical abutment (Morse taper) connection implants: a systematic review. J Biomed Mater Res A. 2014;102:552574.

15. Ricomini Filho AP, Fernandes FS, Straioto FG, Silva WJ, Del Bel Cury AA. Preload loss and bacterial penetration on different implant-abutment connection systems. Braz Dent J. 2010;21:123-129.

16. Siamos G, Winkler S, Boberick KG. The relationship between implant preload and screw loosening on implant-supported prostheses. J Oral Implantol 2002;28:67-73.

17. Kitagawa T, Tanimoto $Y$, Odaki M, Nemoto $K$, Aida M. Influence of implant/abutment joint designs on abutment screw loosening in a dental implant system. J Biomed Mater Res B Appl Biomater 2005;75:457-463.

18. D'Ercole S, Tripodi D, Ravera L, Perrotti V, Piattelli A, lezzi G. Bacterial leakage in Morse cone internal connection implants using different torque values: an in vitro study. Implant Dent 2014;23:175-179.

Received March 30, 2016 Accepted April 4, 2016 